\title{
Notes on some trace fossils and other parataxa from the Maastrichtian type area, southeast Netherlands and northeast Belgium*
}

\author{
S.K. Donovan ${ }^{1,}{ }^{*}$, J.W.M. Jagt ${ }^{2}$ \& D.N. Lewis ${ }^{3}$ \\ 1 Department of Geology, Nederlands Centrum voor Biodiversiteit (Naturalis), Postbus 9517, NL-2300 RA Leiden, the Netherlands. \\ 2 Natuurhistorisch Museum Maastricht, de Bosquetplein 6-7, NL-6211 KJ Maastricht, the Netherlands. \\ 3 The Natural History Museum, Department of Palaeontology, Cromwell Road, London SW7 5BD, United Kingdom. \\ * Corresponding author. Email: Steve.Donovan@ncbnaturalis.nl
}

Manuscript received: October 2010, accepted: January 2011

\begin{abstract}
New specimens described herein add to our knowledge of uncommon parataxa (embedment structures, borings and a certain type of burrow) from the type area of the Maastrichtian Stage, the material originating from the ENCI-HeidelbergCement Group (Maastricht), Ankerpoort-'t Rooth (Bemelen) and former Blom (Berg en Terblijt) quarries in southern Limburg (the Netherlands), and from the CBR-Romontbos (Eben Emael) and CPL SA (Haccourt) chalk pits in the province of Liège (northeast Belgium). Although Centrichnus eccentricus Bromley \& Martinell has previously been recorded from this area, it has not received formal description; the specimen documented herein shares a test of the echinoid Echinocorys gr. conoidea with numerous other episkeletozoans. Podichnus cf. centrifugalis Bromley \& Surlyk occurs both on echinocorythid echinoid tests and guards of belemnitellid coleoids; two out of seven specimens display radial discontinuous channels, indicative of the extreme penetration of filaments from the attached brachiopod's pedicle. Renichnus arcuatus Mayoral shows a range of morphologies, from the embedment structure sensu stricto through to specimens retaining internal moulds of the producing, embedded vermetid gastropod to free shells of Vermetus binkhorsti Cossmann. Burrows packed with bioclastic debris, particularly primary spines and a few test plates of phymosomatid echinoids, present a systematic conundrum, although appearing comparable to the ichnogenera Nummipera Hölder and Baronichnus Breton in several respects.
\end{abstract}

Keywords: Ichnology, systematics, Centrichnus, Podichnus, Renichnus, burrows, Maastrichtian

\section{Introduction}

The ichnology of the extended type area of the Maastrichtian Stage (uppermost Cretaceous, 70.6-65.5 Ma) in the southeast Netherlands and northeast Belgium, has been described over a period of many years in a plethora of short papers by a host of authors. A brief review of the diversity of this ichnofauna was published by Dortangs (1998), while Jagt (2003, p. 181, appendix) provided a tabulation of the ichnotaxa known at that time from the Vaals, Gulpen and Maastricht formations, of early Campanian to latest Maastrichtian age, in this area, but no monographic study exists.

Herein, we add new specimens to three embedments, and provide new observations on morphology and substrate preference. We also illustrate and discuss a distinctive burrow morphology that remains in open nomenclature, but which does show some resemblance to, for example, the ichnogenera Nummipera Hölder, 1989, and Baronichnus Breton, 2002.

Terminology of trace fossil morphology follows Häntzschel (1975; see also De Gibert et al., 2004; Bromley \& Heinberg, 2006). Our approach to ichnotaxonomy conforms to that of Pickerill (1994) and Bertling et al. (2006), while the philosophy of open nomenclature outlined by Bengtson (1988) is adopted here. All specimens are deposited in the collections of the Natuurhistorisch Museum Maastricht (abbreviation: NHMM, with subsets indicated by letters, as follows: JJ - J.W.M. Jagt Collection; MD - M.J.M. Deckers Collection; RZ - S. Renkens/H. Zijlstra Collection; WR - W. van Rijsselt Collection).

* In: Jagt, J.W.M., Jagt-Yazykova, E.A. \& Schins, W.J.H. (eds): A tribute to the late Felder brothers - pioneers of Limburg geology and prehistoric archaeology. 


\section{Localities and horizons}

In the extended type area of the Maastrichtian Stage (Fig. 1), a number of key localities have been selected which, in combination, represent the entire stratigraphic sequence from the middle/upper Santonian to the lowermost Paleocene (middle Danian). The present parataxa originate principally from the former CPL SA-Haccourt (Haccourt, Liège), ENCI-Heidelberg Cement Group (south of Maastricht) and CBR-Romontbos (Eben Emael, Liège) quarries. The stratigraphic levels from which the material stems all relate to the Maastrichtian, and comprise the Vijlen, Lixhe 1 and Lanaye members (Gulpen Formation), as well as the Gronsveld and Meerssen members (Maastricht Formation; see Jagt, 2010 for details).

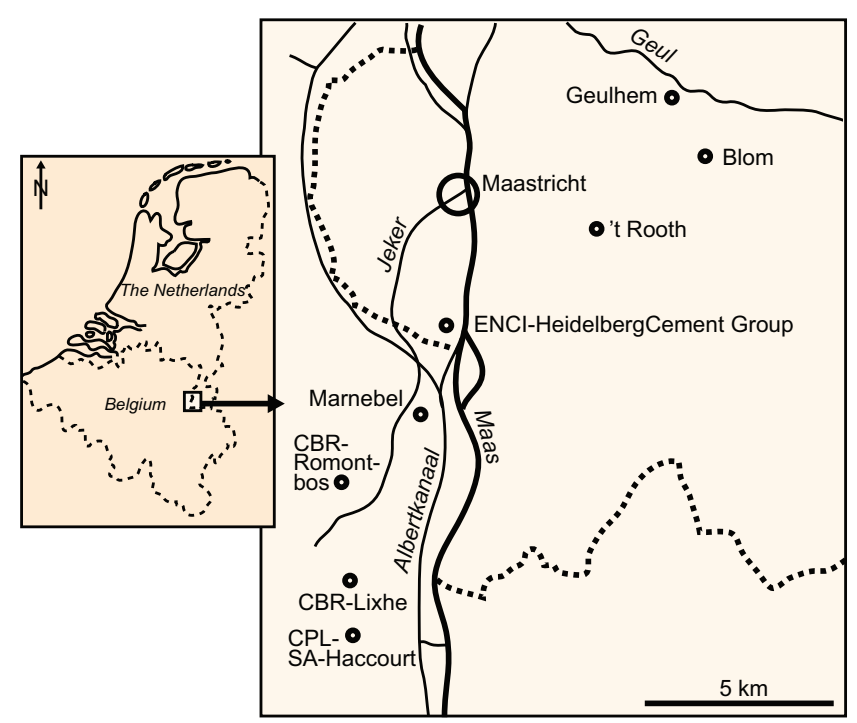

Fig. 1. Map of southern Limburg (the Netherlands) and contiguous Belgian territory, showing a selection of key localities (CPL SA-Haccourt; CBR-Lixhe; CBR-Romontbos; ENCI-HeidelbergCement Group; Blom; Geulhem (Curfs); Marnebel; 't Rooth-Bemelen), inclusive of the ones which yielded the present material.

\section{Systematic ichnology}

Ichnogenus Centrichnus Bromley \& Martinell, 1991

\section{Type ichnospecies}

Centrichnus eccentricus Bromley \& Martinell, 1991, pp. 247-249, figs 5,6 , by original designation.

\section{Other ichnospecies}

Centrichnus concentricus Bromley \& Martinell, 1991.

\section{Diagnosis}

Shallow biogenic etching traces on carbonate lithic or skeletal substrates comprising centrically arranged arcuate or ringshaped grooves (based on Bromley \& Martinell, 1991, p. 247).

\section{Remarks}

The teardrop-shaped $C$. eccentricus, considered to be produced by the byssal plug of anomiid bivalves (Bromley, 1994, p. 145, fig. 5.1B; Taddei Ruggiero \& Annunziata, 2002, p. 48, pl. 2; Bromley \& Heinberg, 2006, table 1), ranges from the lower Campanian to the present day, thus markedly post-dating the first appearance of the Anomiidae in the Middle Jurassic (Bromley, 2004, p. 462). The other ichnospecies, Centrichnus concentricus, is produced by verrucid barnacles; although the Verrucidae have a fairly extended Late Cretaceous record (see Buckeridge et al., 2008), we know of no examples of this ichnotaxon of that age. It should also be noted here that De Gibert et al. (2007, p. 792, fig. 9A, B) recorded small-sized (1.0-1.5 $\mathrm{mm}$ in length) traces from the Pliocene of southern France which they listed as $C$. cf. eccentricus and interpreted as etching (fixation) traces of cibicidid foraminifera.

\section{Centrichnus eccentricus Bromley \& Martinell, 1991}

Fig. 2B.

\section{Material}

One incomplete specimen (Fig. 2B) at about mid-height and to the right of the anterior ambulacrum on a test of Echinocorys gr. conoidea (NHMM WR 1791), just out of view to the right in Fig. 2A.

\section{Locality and horizon}

CPL SA-Haccourt quarry, Haccourt (Oupeye, Liège, northeast Belgium); Gulpen Formation, top $5 \mathrm{~m}$ of Lixhe 1 Member, directly below the Hallembaye 1 Horizon.

\section{Diagnosis}

Tear- or drop-shaped Centrichnus comprising a series of bundled or crowded, bow-shaped grooves concave toward the pointed end (based on Bromley \& Martinell, 1991, p. 247).

\section{Description}

Kidney-shaped depression in the test of an echinoid, the long axis being oriented perpendicular to the oral surface; closelypacked, gently curved, parallel grooves in the base of the depression, parallel to the two long sides of the trace.

\section{Remarks}

Previous reports of $C$. eccentricus from the Maastrichtian type area include Jagt \& Dortangs (2000, figs 2-4) and Jagt (2003, fig. 1). These papers illustrated specimens that were more complete than the one described herein, which lacks a 'pointed end' (see diagnosis above), but $C$. eccentricus from this area has not hitherto received a formal systematic treatment.

The substrate is particularly densely infested by diverse epiand endoskeletozoans, including numerous craniid brachiopods of two species, Crania antiqua Defrance, 1818, and Ancistrocrania aff. parisiensis Defrance, 1818 (see Kruytzer, 1969, p. 12, fig. 2; 


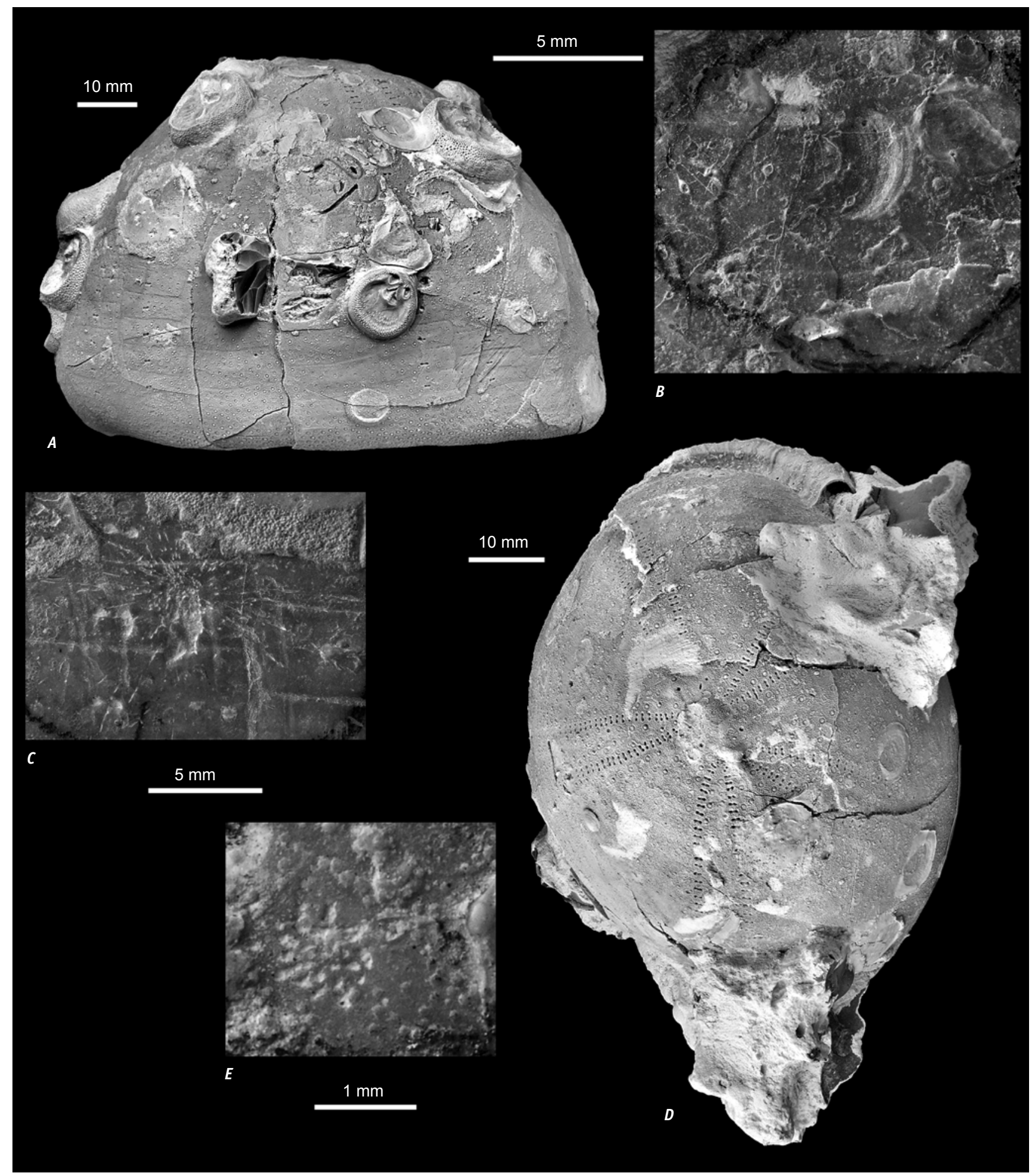

Fig. 2A-C, E. Echinocorys gr. conoidea (Goldfuss, 1829), NHMM WR 1791. A - test in lateral view (anterior towards the right), showing encrusting organisms [mainly the craniid brachiopods Ancistrocrania aff. parisiensis (Defrance, 1818) and Crania antiqua (Defrance, 1818)], although trace fossils are less easily discerned; $B$ - Centrichnus eccentricus Bromley \& Martinell, 1991, incomplete specimen; C - Podichnus cf. centrifugalis Bromley \& Surlyk, 1973, specimen showing discontinuous radial grooves (see also Fig. 3A, B); E - Podichnus cf. centrifugalis Bromley \& Surlyk, 1973; D - Echinocorys gr. conoidea (Goldfuss, 1829), NHMM 2010129 (leg. N. Debrun, deceased), test bored in left-hand side, anterior half, by Podichnus cf. centrifugalis Bromley \& Surlyk, 1973 (see Fig. 3A). Specimens coated with ammonium chloride prior to photography. 
and p. 19, fig. 5, respectively), cyclostome and cheilostome bryozoans, Podichnus cf. centrifugalis Bromley \& Surlyk, 1973 (see below), Oichnus paraboloides? Bromley, 1981, Trypanites? isp. and $C$. eccentricus. The last-named ichnotaxon is closely associated with bryozoans (Fig. 2B); it is positioned just beneath and anterior of the large craniid seen in the upper right of Figure 2A. This test was undoubtedly infested post-mortem, after the loss of all spines, with encrusters covering pore pairs and tubercles without any sign of an adverse reaction by the echinoid (as would be expected in a live individual). Although dead Echinocorys tests were common hard substrates utilised by encrusters and borers in the Late Cretaceous, the two specimens illustrated herein (Fig. 2A, D) seem to have been particularly popular and are typical of at least a quarter (i.e., 25 per cent) of the population of echinocorythid echinoids in the Lixhe 1 Member of the Haccourt-Lixhe-Boirs area (northeast Belgium; JWMJ, pers. obs.). Centrichnus eccentricus is also known from pycnodonteine oyster substrates in the study area (see Jagt, 2003, fig. 1) as well as from another echinoid species, Echinocorys gr. limburgica from the underlying Vijlen Member (interval 6; see Jagt \& Dortangs, 2000, figs 2-4).

\section{Ichnogenus Podichnus Bromley \& Surlyk, 1973}

\section{Type ichnospecies}

Podichnus centrifugalis Bromley \& Surlyk, 1973, p. 364, fig. 13, by original designation.

\section{Other ichnospecies}

Podichnus obliquus Robinson \& Lee, 2008; Podichnus perpendicularis Robinson \& Lee, 2008.

\section{Diagnosis}

More or less compact group or cluster of short pits, holes, elongate cylindrical shafts and/or furrows, mutually parallel or diverging. Surface expression is a c. 1-4 millimetre-sized cluster of holes each up to c. $200 \mu \mathrm{m}$ in diameter (modified after Robinson \& Lee 2008, p. 223).

\section{Remarks}

Robinson \& Lee (2008) included, '... within carbonate substrates' as part of their emended ichnogeneric diagnosis of Podichnus. Substrate is not an ichnotaxobase per se (Pickerill, 1994; Donovan \& Pickerill, 2002), although we do recognise its importance (Andrew et al., 2010, p. 92), but we prefer that it should not form part of the diagnosis. Although not recorded hitherto, a Podichnus in a non-carbonate substrate would still be Podichnus; for example, it might conceivably occur in a lithic or phosphatic clast.

A further ichnospecies of Podichnus is currently being described by Gérard Breton (pers. comm. to SKD, September 2010). Examination of a photograph of the same shows it is not similar to specimens described herein.
Podichnus cf. centrifugalis Bromley \& Surlyk, 1973

Figs 2C, E, 3A, B, 4B-D.

\section{Material}

Two specimens (Fig. 2C, E) below mid-height in right posterior interambulacrum and one above mid-height in right posterior ambulacrum on Echinocorys gr. conoidea (NHMM WR 1791), respectively; one in left posterior interambulacrum of Echinocorys gr. conoidea (NHMM 2010 129) (Fig. 3A); three specimens (Fig. 4A-D) on a belemnite guard, Belemnitella gr. junior Nowak, 1913 (NHMM WR 565); one on a belemnite guard, Belemnella sp. (NHMM WR 936) (not figured); plus one further specimen (Fig. 3B) on a belemnite guard, Belemnitella sp. (NHMM 2010 130, leg. W. van Rijsselt).

\section{Locality and horizon}

NHMM WR 1791 is from the upper part of the Lixhe 1 Member (Gulpen Formation) at the former CPL SA quarry (Haccourt), NHMM 2010129 originates from the same member at the adjoining CBR-Lixhe quarry, while NHMM WR 565, NHMM WR

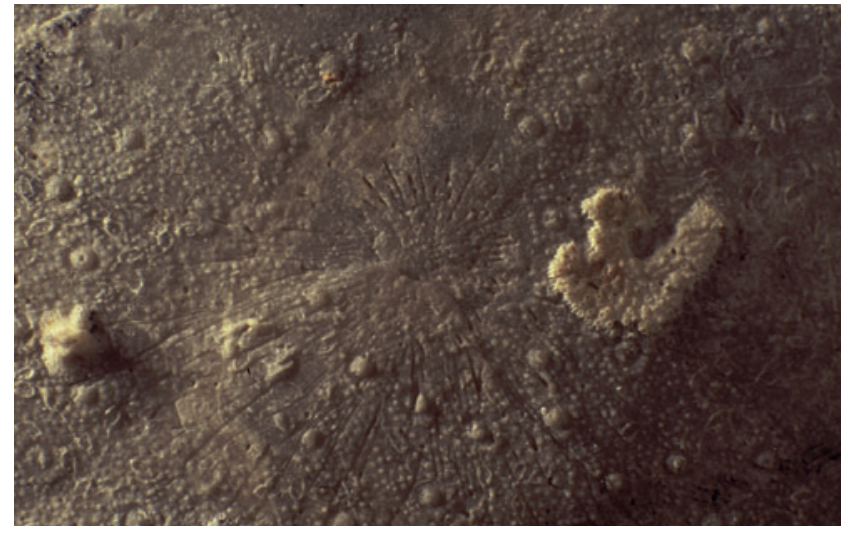

A.

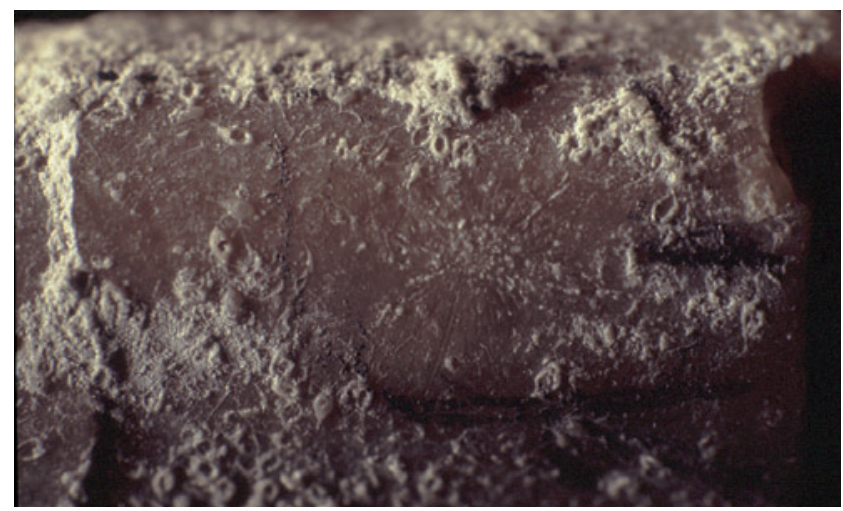

B.

Fig. 3. Podichnus cf. centrifugalis Bromley \& Surlyk, 1973; A - NHMM 2010129 (leg. N. Debrun, deceased), in a test of Echinocorys gr. conoidea (see Fig. 2D); greatest diameter of trace is 13 mm; B - NHMM 2010130 (leg. W. van Rijsselt), in a belemnite guard, Belemnitella sp.; greatest diameter of trace is $4.5 \mathrm{~mm}$. 


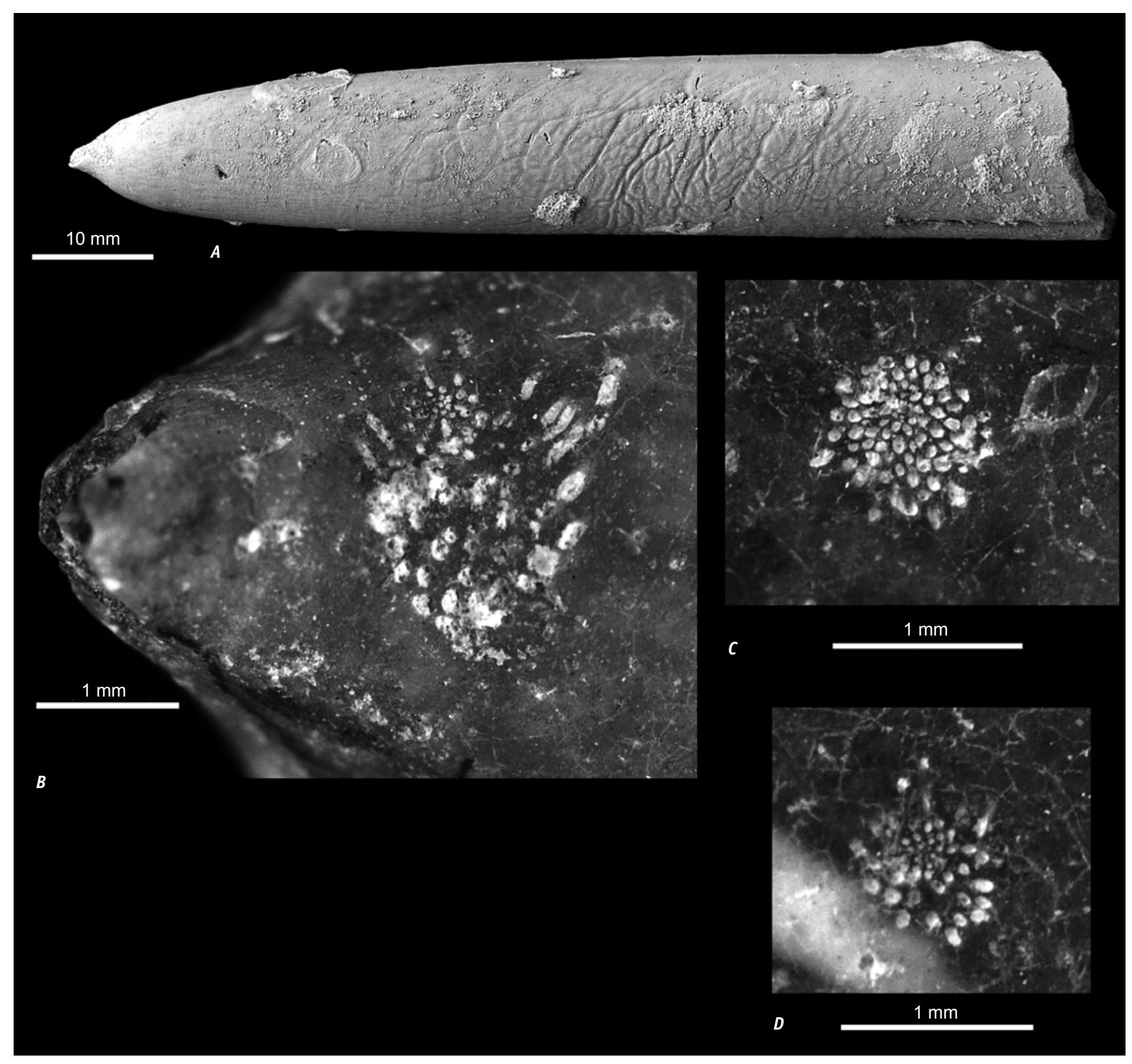

Fig. 4. Belemnitella gr. junior Nowak, 1913, NHMM WR 565. A - guard in oblique lateral view; B-D - Podichnus cf. centrifugalis Bromley \& Surlyk, 1973, all infesting the figured guard - in B two traces can be seen to overlap partially. Specimen coated with ammonium chloride for photography.

936 and NHMM 2010130 are all from the Vijlen Member (near the Zonneberg Horizon; Gulpen Formation) at the ENCIHeidelbergCement Group quarry, Maastricht.

\section{Description}

Small- to medium-sized, rounded clusters of numerous, minute circular to elliptical or, where more closely spaced, roughly polygonal pits in the surface of echinoid tests (Figs 2C, 3A) and belemnite guards (Figs 2E, 3B, 4B-D). One specimen (Fig. 4B) appears to consist of two partially overlapping traces, as is suggested by the strong differentiation between rounded and more elongate pits as well as their size. Three specimens (that is, Figs $2 \mathrm{C}, 3 \mathrm{~A}, \mathrm{~B}$ ), two of which (Figs $2 \mathrm{C}, 3 \mathrm{~A}$ ) are of comparatively large size (that is, greatest diameters of 13 and $11 \mathrm{~mm}$, respectively, the latter partially overgrown by a pycnodonteine oyster), have a strong radial development of discontinuous grooves in addition to a cluster of circular and elliptical pits in the centre.

\section{Remarks}

The only previous report of Podichnus from the type area of the Maastrichtian Stage was that by Jagt et al. (2007), who described two specimens of $P$. centrifugalis on a test of Echinocorys gr. conoidea from the Lixhe 1 Member at the CPL SA quarry (Haccourt, Liège) and discussed possible agents amongst the brachiopod assemblages known from this level.

Here we opt to leave our Podichnus specimens in open nomenclature. When this ichnogenus comprised only one 
ichnospecies, identification of $P$. centrifugalis was possible from external morphology alone. Now that there are four ichnospecies, at least one carefully oriented section cut through the substrate or the production of an epoxy cast would be required of each specimen to determine its precise morphology. For now, we refrain from such destructive preparation. However, the external morphology of all specimens described herein is closest to the type ichnospecies, with the exception of those illustrated in Figures $2 \mathrm{C}$ and $3 \mathrm{~A}, \mathrm{~B}$, which are atypical in showing a strong radial component of discontinuous grooves; they may represent another, perhaps new ichnospecies. These provide unusual evidence of the extreme degree of insertion of filaments of the brachiopod pedicle into the echinoid test. Although functionally different, the rootlets of the extant abyssal soft-sediment dweller Childonophora Thomson, 1927, provide an indication of the fine branching possible in such a structure (Rudwick, 1970, fig. 36). It is interesting to note that, unlike occurrences elsewhere (see, for example, Małkowski, 1975; Taddei Ruggiero \& Annunziata, 2002; Žítt et al., 2006), we know of no Podichnus traces on any brachiopod shells from the study area.

\section{Ichnogenus Renichnus Mayoral, 1987}

\section{Type ichnospecies}

Renichnus arcuatus Mayoral, 1987, pp. 56-57, fig. 3; pl. 2, fig. 13, by original designation.

\section{Other ichnospecies}

None.

\section{Diagnosis}

Kidney-shaped depressions in the form of a half moon, disposed in a crude row or coarsely coiled (after Mayoral, 1987, p. 56; translated from Spanish).

\section{Remarks}

This monospecific ichnogenus is easily differentiated from the superficially similar Centrichnus eccentricus by being composed of relatively few adjacent, concentric depressions that are less gracile (compare with Jagt, 2003, fig. 1).

Renichnus arcuatus Mayoral, 1987

Figs 5-7.

\section{Material}

Renichnus arcuatus (sensu stricto): NHMM RZ 00887 (ex 98A; see Fig. 5A) and NHMM WR 1845 (Fig. 7); miscellaneous vermetid moulds and shells, including NHMM JJ 7443 (Fig. 5E), JJ 8456 (Fig. 5I), JJ 11485a, b (Fig. 6A, B), JJ 12389 (Fig. 5H), JJ 13559 (Fig. 5B, C), JJ 13560 (Fig. 5G), JJ 14249 (Fig. 5J), JJ 14257 (Fig. 5F) and NHMM RZ 02108 (ex 319) (Fig. 5D). These mainly infest colonial scleractinian corals of various types, with the exception of NHMM WR 1845, which occurs in a calcareous serpulid tube.

\section{Locality and horizon}

All material originates from subunit IVf-4 of the Meerssen Member (Maastricht Formation), of late Maastrichtian age, at the ENCI-HeidelbergCement Group (Maastricht; NHMM JJ 7443, JJ 8456, JJ 11485a, b, JJ 12389, JJ 13559a, JJ 13560, JJ 14249 and JJ 14257) and former Blom (Berg en Terblijt; NHMM RZ 02108) quarries, except for NHMM RZ 00887, which is from the base of subunit IVf-3 at the former Blom quarry and NHMM WR 1845, which stems from the basal Meerssen Member at the Ankerpoort - 't Rooth quarry.

\section{Diagnosis}

As for the ichnogenus.

\section{Description}

Reference is made to Jagt (2003, p. 177) and Jagt et al. (2009, p. 159) for descriptions of $R$. arcuatus from the type Maastrichtian. Other records of this ichnospecies include Radwański (1977, pp. 246-247), Mayoral (1987, pp. 56-57), Donovan (2004, p. 139) and Taddei Ruggiero \& Raia (2010, p. 163, as Renichnus arquatus).

\section{Remarks}

To demonstrate the range of morphologies possible, we here illustrate $R$. arcuatus (sensu stricto), along with external and internal moulds of vermetid gastropods, and their shells (Figs $5,6)$. These serve to demonstrate the problem of determining where preservation of embedment structures stops and body fossil preservation starts. Many specimens are part body fossil and part embedment structure. Perhaps most confusing is NHMM JJ 13559 (Fig. 5B, C), best described as an external mould of Vermetus binkhorsti Cossmann, 1902 (= V. clathratus Binkhorst van den Binkhorst, 1861, p. 35, pl. 5a2, fig. 3, non Deshayes 1861, p. 286, pl. 9, figs. 9, 10, as Serpulorbis clathratus); if not for the infill of the hollow columella this would have been better regarded as $R$. arcuatus. Renichnus arcuatus is also known from shells of exogyrine oysters and calcareous serpulid worm tubes in the study area (Fig. 7; see also Jagt 2003, pl. 2, fig. 3; Jagt et al. 2009, fig. 1).

\section{Burrows packed with bioclastic debris}

Fig. 8.

\section{Material}

Two large pieces, NHMM JJ 11983a, b (part of the same specimen) (Fig. 8A, B, D, F) and two smaller pieces, also of the same burrow, NHMM MD 4952/24 (Fig. 8C, E, G). 

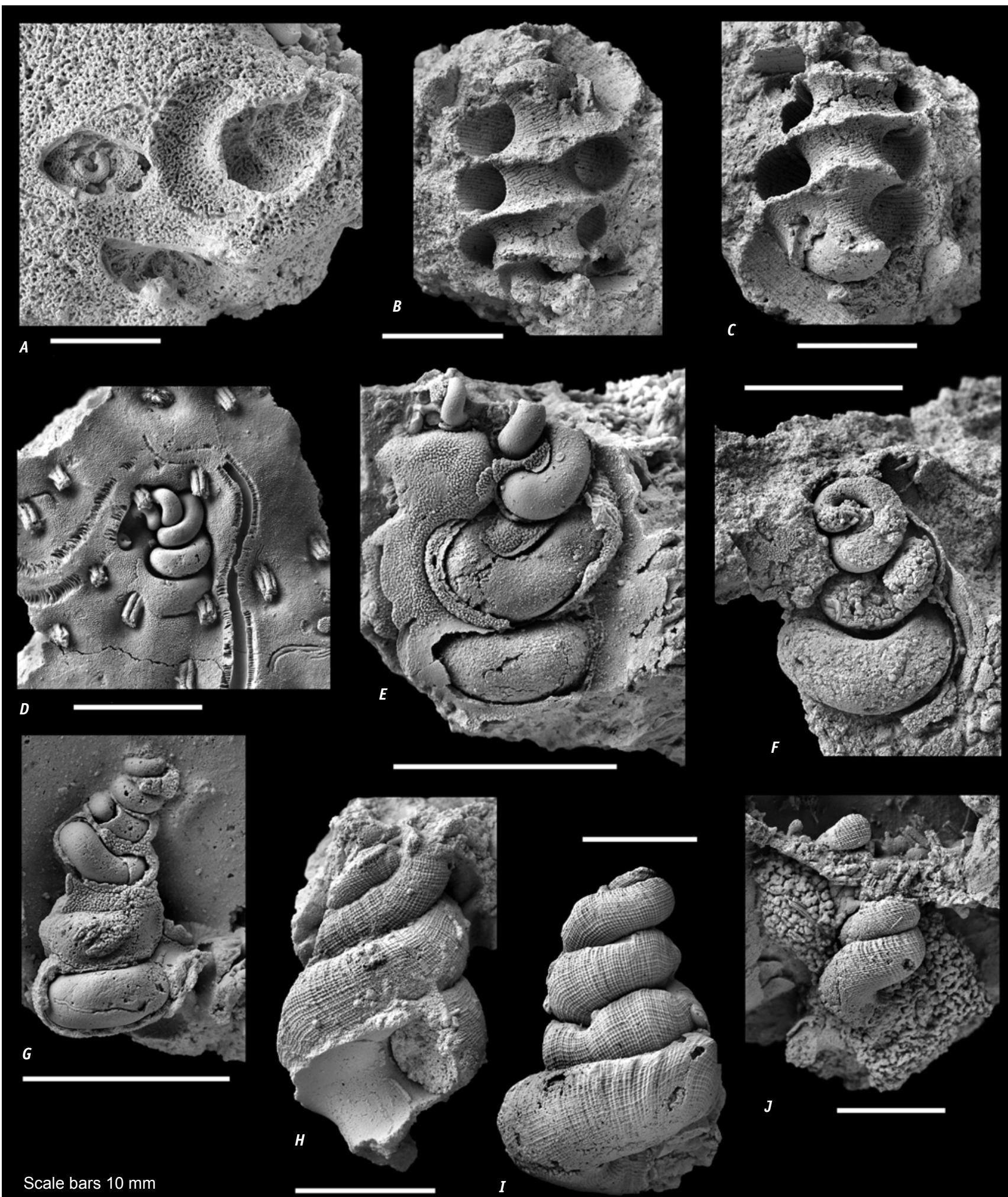

Scale bars $10 \mathrm{~mm}$

Fig. 5. Vermetid gastropods and their embedment structures. A - Renichnus arcuatus Mayoral, 1987, NHMM RZ 00887 (ex 98A); B, C - Vermetus binkhorsti Cossmann, 1902, NHMM JJ 13559a, external mould, two views of same specimen, inverted in relation to each other; D - vermetid internal mould, NHMM RZ 02108 (ex 319), in R. arcuatus; E - vermetid internal mould, NHMM JJ 7443; F-vermetid internal mould, NHMM JJ 14257; G - V. binkhorsti, NHMM JJ 13560, internal mould retaining some part of cast of shell; H - V. binkhorsti, NHMM JJ 12389; I - V. binkhorsti, NHMM JJ 8456, previously illustrated by Jagt (2003, pl. 2, fig. 4); J - V. binkhorsti, NHMM JJ 14249. Specimens coated with ammonium chloride prior to photography. 


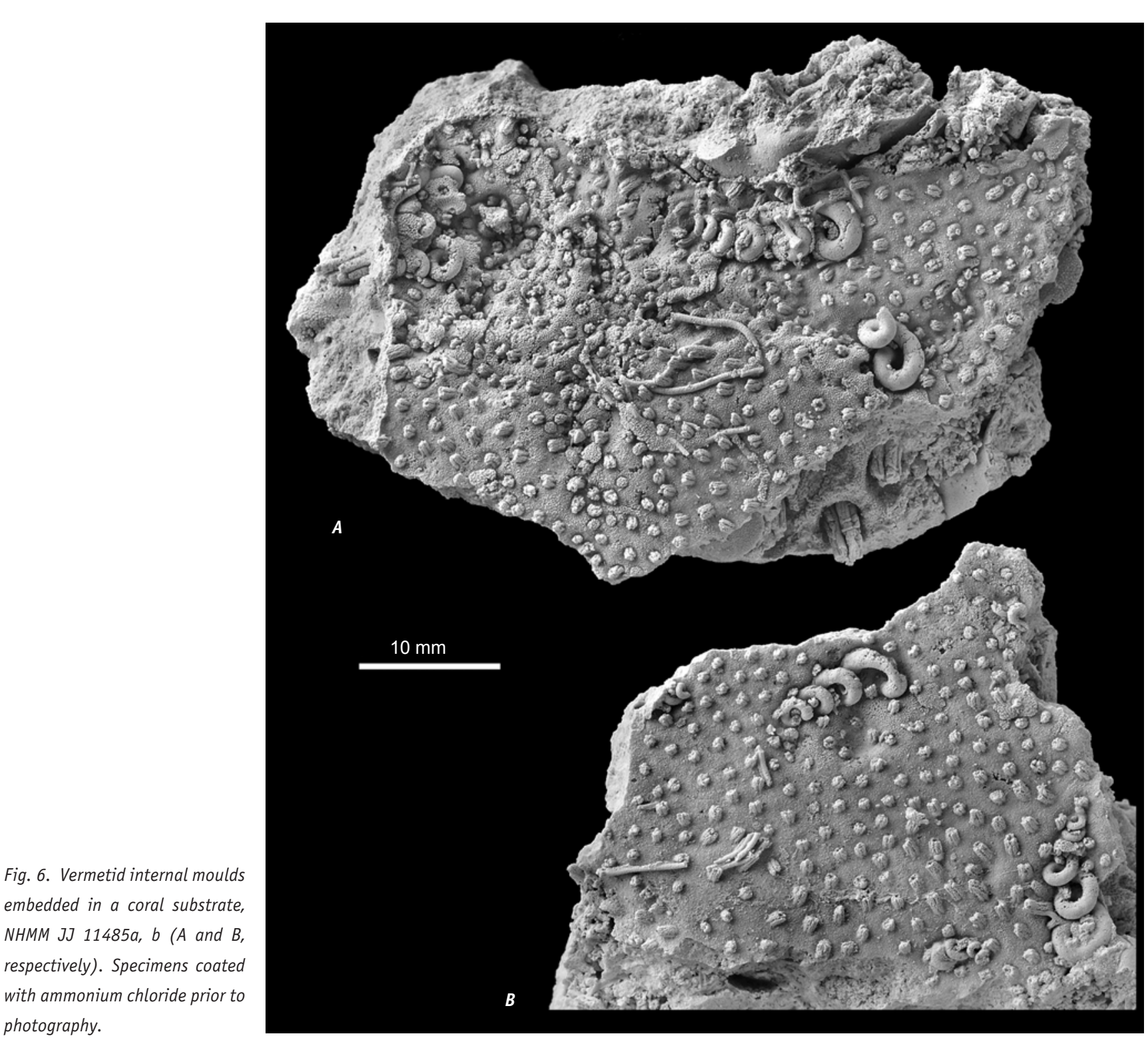

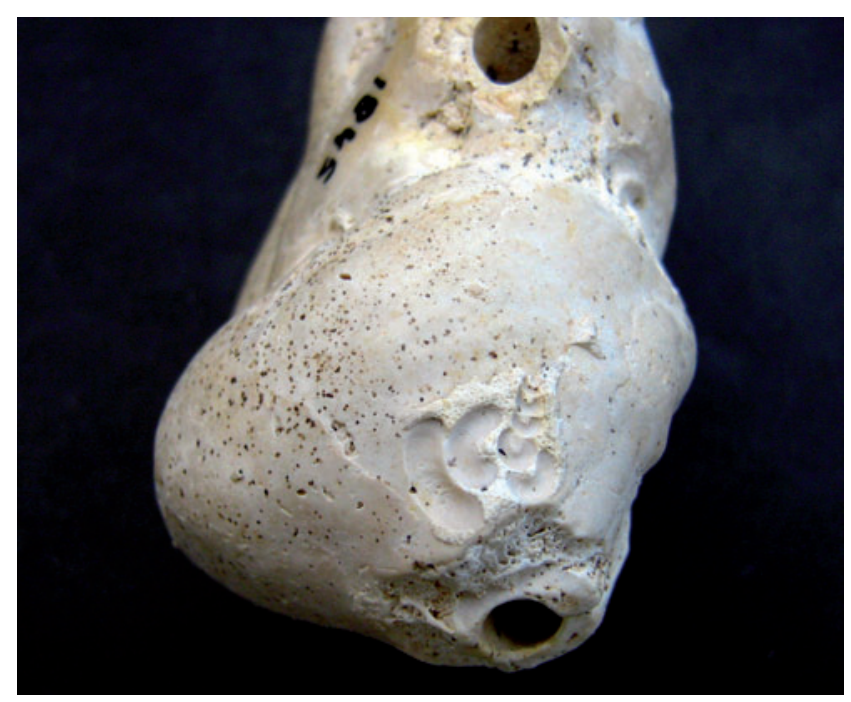

Fig. 7. Renichnus arcuatus on a serpulid tube (NHMM WR 1845) from the basal Meerssen Member at the 't Rooth (Ankerpoort) quarry (Bemelen); greatest length of trace is $9.5 \mathrm{~mm}$.

\section{Locality and horizon}

NHMM JJ 11983a, b is from the basal Gronsveld Member (Maastricht Formation; ENCI Horizon $+0.2 \mathrm{~m}$ ) at the ENCIHeidelbergCement Group quarry, while NHMM MD 4952/24 stems from between flint levels 16 and 17 of the Lanaye Member (Gulpen Formation) at the CBR-Romontbos quarry.

\section{Remarks}

NHMM JJ11983a, b appears to be a massive fill of an unlined burrow (cf. Planolites isp.); it was collected in situ in a vertical position, the widest part up. In contrast, NHMM MD 4952/24 is lined with echinoid debris (a skeletal debris wall sensu Keighley \& Pickerill, 1994, text-fig. 1) with a fill which is more coarsely grained and more obviously laminated than the enclosing lithology; the fill is not meniscate. Unfortunately, the original position in the sediment has not been noted during collection. Stated bluntly, an unbranched burrow with a fill of different morphology to the surrounding sedimentary rock is not 


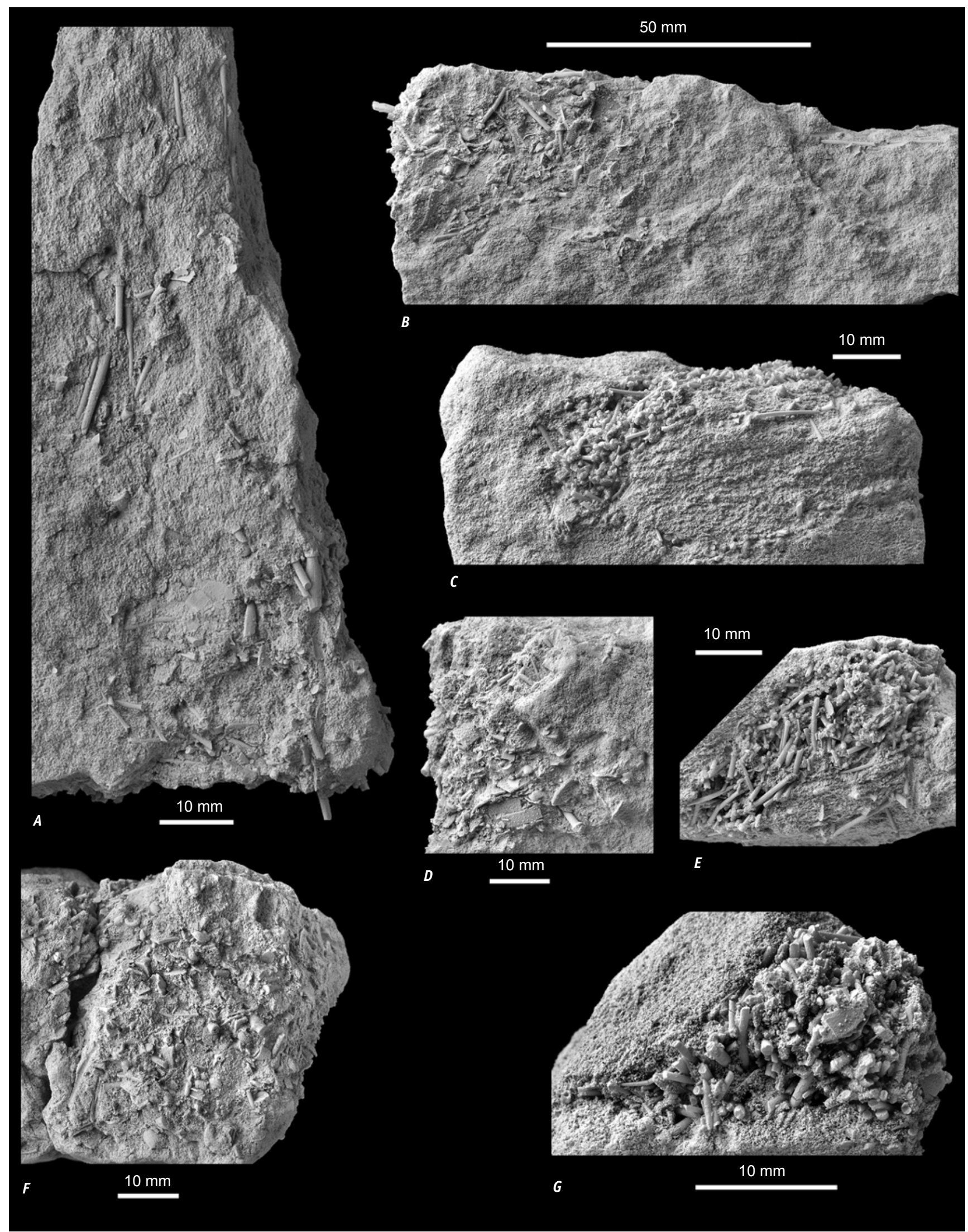

Fig. 8. Burrows packed with bioclastic debris. A, B - two views of a large specimen, NHMM JJ 11983a; C, E, G - three views of two pieces of the same, small specimen, NHMM MD 4952/24; D, F- two views of clasts, NHMM JJ 11983b. Specimens coated with ammonium chloride prior to photography. 
particularly unusual, but, despite obvious similarities between these specimens (Fig. 8), the lined burrow is rather different to Planolites isp. and these specimens represent different ichnogenera, although both are left in open nomenclature. They are here included together for the single purpose of drawing attention to them.

These burrows are remarkable for their fill which is dominated by echinoid fragments, mainly primary spines of the small- to medium-sized phymosomatid Gauthieria pseudoradiata auctt. (?non Schlüter, 1883; see Jagt, 2000, pp. 233-236, for discussion), but also fragments of the test. In addition, isolated spines of Trochalosoma corneti (Cotteau, 1875) (inops morphotype; see Jagt, 2000, pl. 13, figs 3-7) and fragments of pectinoid bivalves, scalpellid cirripedes, micrasterid echinoids, astropectinid asteroids, cheilostome and cyclostomes bryozoans, bourgueticrinid columnals and brachials, fish scales and ophiolepidid brittlestars, plus a single ?nautiloid conchorhynch (Conchorhynchus limburgicus Van der Tuuk, 1982) have been recognised. These are unlikely to be selective hydrodynamic accumulations and most probably represent the result of selective scavenging or predation by burrowing organism(s) unknown. Their interest is thus mainly palaeobiological. In certain respects (that is, overall (near)cylindrical shape and consistency of material selected to reinforce the burrow wall), there is a resemblance to Nummipera Hölder, 1989, and Baronichnus Breton, 2002. Nummipera eocenica Hölder, 1989 (p. 25, fig. 9), which constitutes a burrow (of domichnion type) whose wall consists of larger benthic foraminifera, mainly nummulitids, was first described from the Eocene of Split (Croatia). However, Breton (2004) subsequently demonstrated that this ichnotaxon was not validly introduced and should be treated as a nomen dubium. In contrast, Baronichnus armatus Breton, 2002 (p. 32, figs 2-9), from the lower/middle Turonian interval of Touraine (France), is a valid ichnotaxon, erected to accommodate subvertical and tubular burrows, whose wall is reinforced with bryozoan zoaria horizontally placed within that wall.

\section{Acknowledgements}

Phil Crabb (Photographic Unit, the Natural History Museum, London) is thanked for producing the excellent images of Figures 2, 4-6 and 8, while Anne S. Schulp (Natuurhistorisch Museum Maastricht), Rudi W. Dortangs (Amstenrade/Bonn) and W. van Rijsselt (Maastricht) supplied Figures 1, 3A, B and 7, respectively. Thought-provoking reviews by Gérard Breton (Le Havre) and Markus Bertling (Münster) are gratefully acknowledged.

\section{References}

Andrew, C., Howe, P., Paul, C.R.C. \& Donovan, S.K., 2010. Fatally bitten ammonites from the lower Lias Group (Lower Jurassic) of Lyme Regis, Dorset. Proceedings of the Yorkshire Geological Society 58: 81-94.

Bengtson, P., 1988. Open nomenclature. Palaeontology 31: 223-227.

Bertling, M., Braddy, S.J., Bromley, R.G., Demathieu, G.R., Genise, J., Mikuláš, R., Nielsen, J.K., Nielsen, K.S.S., Rindsberg, A.K., Schlirf, M. \& Uchman, A., 2006. Names for trace fossils: a uniform approach. Lethaia 39: 265-286.

Binkhorst van den Binkhorst, J.-T., 1861. Monographie des Gastéropodes et des Céphalopodes de la Craie supérieure du Limbourg, suivie d'une description de quelques espèces de Crustacés du même dépôt crétacé, avec dix-huit planches dessinées et lithographiées par C. Hohe, de Bonn. A. Murquardt (Bruxelles) and Muller Frères (Maastricht): vi + 1-83, 1-44.

Breton, G., 2002. Baronichnus armatus igen. nov., isp. nov.: un fouisseur du tuffeau turonien de Touraine arme son terrier de bryozoaires. Bulletin trimestriel de la Société Géologique de Normandie et des Amis du Muséum du Havre 87 (for 2000): 29-37.

Breton, G., 2004. Nummipera eocenica Hölder, 1989 est un nomen dubium pour un ichnotaxon douteux. Bulletin de la Société Géologique de Normandie et des Amis du Muséum du Havre 90 (for 2003): 43-44.

Bromley, R.G., 1981. Concepts in ichnotaxonomy illustrated by small round holes in shells. Acta Geológica Hispánica 16: 55-64.

Bromley, R.G., 1994. The palaeoecology of bioerosion. In: Donovan, S.K. (ed.): The palaeobiology of trace fossils. John Wiley \& Sons (Chichester): 134-154.

Bromley, R.G., 2004. A stratigraphy of marine bioerosion. In: McIlroy, D. (ed.): The application of ichnology to palaeoenvironmental and stratigraphic analysis. Geological Society Special Publication 228: 455-479.

Bromley, R.G. \& Heinberg, C., 2006. Attachment strategies of organisms on hard substrates: a palaeontological view. Palaeogeography, Palaeoclimatology, Palaeoecology 232: 429-453.

Bromley, R.G. \& Martinell, J., 1991. Centrichnus, new ichnogenus for centrically patterned attachment scars on skeletal substrates. Bulletin of the Geological Society of Denmark 38: 243-252.

Bromley, R.G. \& Surlyk, F., 1973. Borings produced by brachiopod pedicles, fossil and Recent. Lethaia 6: 349-365.

Buckeridge, J.S., Jagt, J.W.M. \& Speijer, R.P., 2008. Verruca punica, a new species of verrucomorph barnacle (Crustacea, Cirripedia, Thoracica) from the Lower Danian (Paleocene) of Tunisia. Zootaxa 1844: 37-46.

Cossmann, M., 1902. Rectifications de nomenclature. Revue critique de Paléozoologie 6: 161.

Cotteau, G., 1875. Note sur les échinides crétacés de la province du Hainaut. Bulletin de la Société géologique de France (3)2: 638-660.

Defrance, M.J.L., 1818. Cranie (Foss.). In: Levrault, F.G. (ed.): Dictionnaire des Sciences naturelles 11: 312-314.

Deshayes, G.P., 1856-1865. Description des animaux sans vertèbres découverts dans le Bassin de Paris, 1-3. J.-B. Baillière (Paris): 1-912.

De Gibert, J.M., Domènech, R. \& Martinell, J., 2004. An ethological framework for animal bioerosion trace fossils upon mineral substrates with proposal of a new class, fixichnia. Lethaia 37: 429-437.

De Gibert, J.M., Domènech, R. \& Martinell, J., 2007. Bioerosion in shell beds from the Pliocene Roussillon Basin, France: implications for the (macro)bioerosion ichnofacies model. Acta Palaeontologica Polonica 52: 783-798. 
Donovan, S.K., 2004. The ichnofossil Renichnus arcuatus Mayoral, 1987 in the Pleistocene of Jamaica. Bulletin of the Mizunami Fossil Museum 30 (for 2003): 137-140.

Donovan, S.K. \& Pickerill, R.K., 2002. Pattern versus process or informative versus uninformative ichnotaxonomy: Reply to Todd and Palmer. Ichnos 9: 85-87.

Dortangs, R.W., 1998. Sporenfossielen. In: Jagt, J.W.M., Dhondt, A.V. \& Leloux, J. (eds): Limburgnummer 9B: Fossielen van de St. Pietersberg. Grondboor \& Hamer 52: 150-151, pl. 28.

Goldfuss, A., 1829. Petrefacta Germaniae tam ea, quae in museo universitatis regiae Borussicae Fridericiae Wilhelmiae Rhenanae servantur quam alia quae cunque in museis hoeninghausiano, muensteriano aliisque extant, iconibus et descriptionibus illustrate. Abbildungen und Beschreibungen der Petrefacten Deutschlands und der angränzenden Länder, unter Mitwirkung des Herrn Grafen Georg zu Münster. Arnz \& Co. (Düsseldorf): 77-164, pls 26-50.

Häntzschel, W., 1975. Trace fossils and problematica $\left(2^{\text {nd }}\right.$ edition, revised and enlarged). In: Teichert, C. (ed.): Treatise on Invertebrate Paleontology, Part W, Miscellanea, Supplement 1. Geological Society of America (Boulder) and University of Kansas Press (Lawrence): xxi + 1-269.

Hölder, H., 1989. Spuren auf der Spur. Palichnologische und verwandte Notizen über Teredolites, Entobia, Nummipera nov. gen. und einiges andere. Münstersche Forschungen zur Geologie und Paläontologie 69: 13-30.

Jagt, J.W.M., 2000. Late Cretaceous-Early Palaeogene echinoderms and the K/T boundary in the southeast Netherlands and northeast Belgium - Part 4: Echinoids. Scripta Geologica 121: 181-375.

Jagt, J.W.M., 2003. The ichnofossil genera Radulichnus and Renichnus in the Maastrichtian of the Netherlands and Belgium. Bulletin de l'Institut royal des sciences naturelles de Belgique, Sciences de la Terre 73: 175-184.

Jagt, J.W.M., 2010. Upper Cretaceous and Lower Paleogene in the type area of the Maastrichtian Stage (70.6-65.5 Ma). Berichte des Instituts für Geowissenschaften, Christian-Albrechts-Universität Kiel 23: 1-21.

Jagt, J.W.M. \& Dortangs, R.W., 2000. Opmerkelijke Luiks-Limburgse Krijtfossielen. Deel 4. Goedzittende paardezadels. Natuurhistorisch Maandblad 89: 183-186.

Jagt, J.W.M., Dortangs, R., Simon, E. \& Van Knippenberg, P., 2007. First record of the ichnofossil Podichnus centrifugalis from the Maastrichtian of northeast Belgium. Bulletin de l'Institut royal des Sciences naturelles de Belgique, Sciences de la Terre 77: 95-105.

Jagt, J.W.M., Van Rijsselt, W. \& Van Rijsselt, E., 2009. Opmerkelijke LuiksLimburgse Krijtfossielen. Deel 13. Honkvaste slakken. Natuurhistorisch Maandblad 98: 159-161.

Keighley, D.G. \& Pickerill, R.K., 1994. The ichnogenus Beaconites and its distinction from Ancorichnus and Taenidium. Palaeontology 37: 305-337.

Kruytzer, E.M., 1969. Le genre Crania (sic) du Crétacé supérieur et du postMaastrichtien de la province de Limbourg néerlandais (Brachiopoda, Inarticulata). Publicaties van het Natuurhistorisch Genootschap in Limburg 19: 1-42.

Małkowski, K., 1975. Attachment scars of the brachiopod Coenothyris vulgaris (Schlotheim, 1820) from the Muschelkalk of Upper Silesia. Acta Geologica Polonica 25: 275-283.

Mayoral, E., 1987. Acción bioerosiva de Mollusca (Gastropoda, Bivalvia) en el Plioceno Inferior de la Cuenca del Bajo Guadalquivir. Revista Española de Paleontología 2: 49-58.
Nowak, J., 1913. Untersuchungen über die Cephalopoden der oberen Kreide in Polen. III. Teil. Bulletin international de l'Académie des Sciences de Cracovie, Classe des Sciences mathématiques et naturelles B1913: 335-415.

Pickerill, R.K., 1994. Nomenclature and taxonomy of invertebrate trace fossils. In: Donovan, S.K. (ed.): The palaeobiology of trace fossils. John Wiley \& Sons (Chichester): 3-42.

Radwański, A., 1977. Present-day types of trace in the Neogene sequence; their problems of nomenclature and preservation. In: Crimes, T.P. \& Harper, J.C. (eds): Trace fossils 2. Geological Journal, Special Issue 9. Seel House Press (Liverpool): 227-264.

Robinson, J.H. \& Lee, D.E., 2008. Brachiopod pedicle traces: recognition of three separate types of trace and redefinition of Podichnus centrifugalis Bromley \& Surlyk, 1973. In: Harper, D.A.T., Long, S.L. \& Nielsen, C. (eds): Brachiopods: fossil and Recent. Fossils and Strata 54: 219-225.

Rudwick, M.J.S., 1970. Living and fossil Brachiopods. Hutchinson (London): 1-199. Schlüter, C., 1883. Die regulären Echiniden der norddeutschen Kreide. I. Glyphostoma (Latistellata). Abhandlungen der königlichen preussischen geologischen Landesanstalt 4: iv + 1-72

Taddei Ruggiero, E. \& Annunziata, G., 2002. Bioerosion on a Terebratula scillae population from the Lower Pleistocene of Lecce area (southern Italy). Acta Geologica Hispanica 37: 43-51.

Taddei Ruggiero, E. \& Raia, P., 2010. Bioerosion structures and their distribution on shells of the Lower Pleistocene terebratulid brachiopod Gryphus minor. Palaeogeography, Palaeoclimatology, Palaeoecology 293: 157-166.

Thomson, J.A., 1927. Brachiopod morphology and genera (Recent and Tertiary). New Zealand Board of Science and Arts, Manual 7: xv + 1-338.

Van der Tuuk, L.A., 1982. A Maastrichtian conchorhynch (Conchorhynchus limburgicus n. sp., Cephalopoda) from Limburg, the Netherlands. Geologie en Mijnbouw 61: 179-182.

Žitt, J., Vodrážka, R., Hradecká, L., Svobodová, M. \& Zágoršek, K., 2006. Late Cretaceous environments and communities as recorded at Chrtníky (Bohemian Cretaceous Basin, Czech Republic). Bulletin of Geosciences 81: 43-79. 